\title{
Trade Openness Effect on Provincial Economic Growth in Indonesia
}

\author{
Saimul, Arif Darmawan \\ Department of Economic Development, University of Lampung \\ Email: sai_mul@yahoo.com
}

A R T I C LE INFO

Date of entry:

02 July 2020

Revision Date:

15 August 2020

Date Received:

05 September 2020

\begin{abstract}
A B S T R A C T
This research aims to analyze the effect of openness on the economic growth of provinces in Indonesia. Using panel data from 2010 to 2017 in six provinces in Indonesia with investment and labor control variables, the results show that trade openness has an essential contribution to improving economic growth in Indonesia's provinces. The methodology of this study is use regression panel model. These results are following the concepts of theory and empiricism. However, because the degree of openness of provincial trade in Indonesia is still relatively low, the positive influence contributing to the domestic economy is also relatively low, from the control of foreign investment, FDI, and labor, which has a negative effect.
\end{abstract}

Keywords: Economic Growth, FDI, Fixed Effects, Panel Data, Trade Openness

Cite this as: Saimul, S., Darmawan, A. (2020). Trade Openness Effect on Provincial Economic Growth in Indonesia. Wiga: Jurnal Penelitian Ilmu Ekonomi, 1O(2), 87100. https://doi.org/10.30741/wiga.v10i2.553

\section{INTRODUCTION}

Economic relations between countries include exchanges of output, labor, capital, and technology from each country. Many countries make economic cooperation relations with other countries through international trade, called the open economy (trade openness). Countries with open economies are countries that carry out export-import activities of goods or services and borrow or provide investment loans through world capital markets. (Mankiw, 2005). Economic openness illustrates the reduced barriers to conducting trade between countries and the higher share of trade, also benefiting all countries involved. Countries become connected. An open economy can improve economic efficiency and competitiveness.

Trade openness can also provide an opportunity for each country to export goods whose production factors use abundant resources and import goods whose production factors are scarce or expensive if produced domestically. Also, it believes to be able to encourage economic growth in a country. Through international trade, developing countries can import new technology from developed countries. Technological development from developed countries is considered as an 
essential factor in the process of economic growth because it can increase labor productivity, capital, and other factors of production.

According to Salvatore (2014), international trade can be an engine for growth (trade as an engine of growth). This study takes a sample of provinces in Indonesia that have average to medium trade openness that can be seen in Table 1. Six provinces have moderate to average trade openness values, namely Riau Islands Province, DKI Jakarta, South Kalimantan, East Kalimantan, Banten, and Bangka Belitung.

Table 1. Average Trade Disclosure in Six Provinces in Indonesia year 2010-2017

\begin{tabular}{|c|c|}
\hline Province & Openness (\%) \\
\hline Kepulauan Riau & 201 \\
\hline DKI Jakarta & 120 \\
\hline South Borneo & 109 \\
\hline East Kalimantan & 82 \\
\hline Banten & 64 \\
\hline Bangka Belitung & 53 \\
\hline
\end{tabular}

Source: BPS (2018)

Rate Openness =

$(\mathrm{X}+\mathrm{M}) \times 100 \%$

PDRB

Indonesia is a developing country that has long implemented an open economic system. The evident from Indonesia's participation in several free trade area agreements. The level of trade openness measured by the sum of exports and imports to GDP.

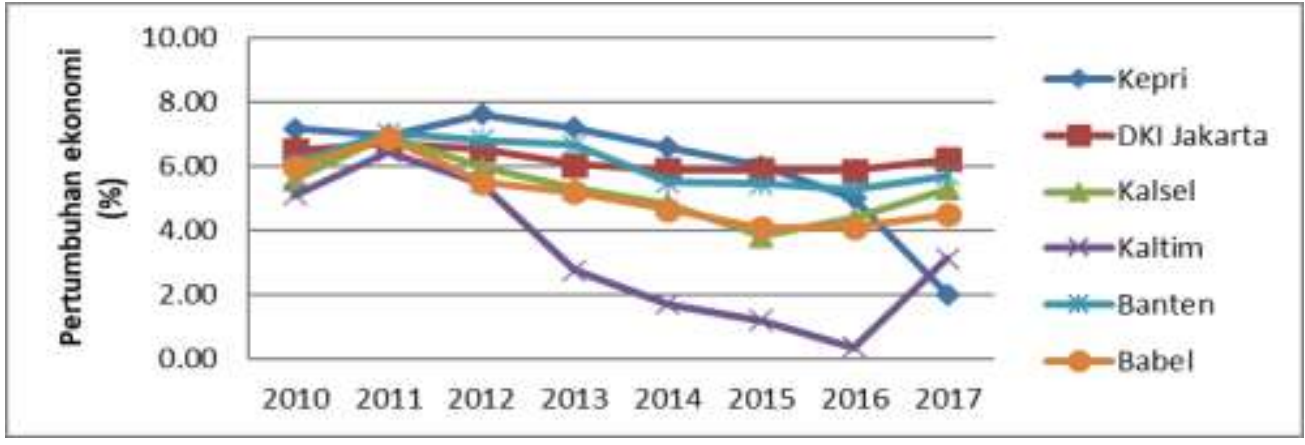

Figure 1. Economic Growth of Six Provinces in Indonesia in 2010-2017 Source: BPS (2018)

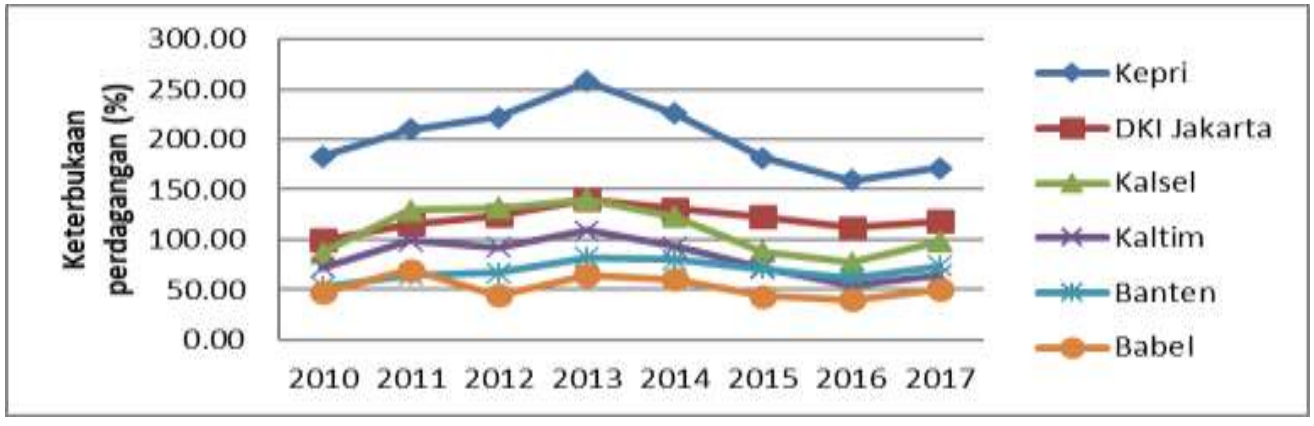

Figure 2. Trade Disclosure of Six Provinces in 2010-2017

Source: BPS (2018) 
Nowbutsing (2014), the level of openness can be classified into three categories, namely less than $50 \%$ included in the category of the low level of openness, more than 50\% and less than $100 \%$ included in the category of medium level of openness and more than $100 \%$ included in the category of the high level of openness. Nevertheless, the increase in trade openness in Indonesia is not always followed by an increase in economic growth, as shown in Figure 1 and Figure 2, which each shows the development of economic growth and trade openness of the six provinces in 20102017.

The situation, as carried out by Buckman (2005) in Ashiddiqi (2011) states that a study conducted by two economists from the World Bank, namely Dollar and Kraay (2000), has shown that more open countries experienced an increase in the economic growth of 2.9 percent in the 1990s. In contrast, more closed countries experienced a decline in the economic growth of 3.3 percent in the 1970 s to 0.80 percent in the 1980 s and 1.4 percent in the 1990 s. This situation shows that the relationship between trade openness and economic growth is not in the same direction.

In addition to foreign trade, foreign investment also plays a vital role in driving economic growth. The foreign investment consists of direct investment (FDI) and indirect investment (portfolio). With the direct investment, a country can access technology from more developed countries, spillover creation can increase trade volume, and can accelerate the rate of economic growth because the factors of domestic production will be better in quality and quantity. Investment is one of the factors driving economic growth.

Countries that have an open economy not only get capital flow from abroad but will also enter the world market, so they must export and import. Both exports and imports are essential factors in stimulating a country's economic growth. Import is an activity of purchasing or importing goods from abroad into a domestic economy (Sukirno, 2004). Through imports, the country can obtain products or goods that cannot be produced domestically. According to the comparative advantage theory (Salvatore, 2014), import activities will be more profitable for a country compared to selfproducing but inefficient.

As explained earlier, foreign trade can increase domestic production, which means that the use of production factors also increases including employment, because the output market is more extensive and domestic companies will increase their production, employment opportunities will also increase. This will benefit a country that has a large population like Indonesia, given that Indonesia has a fourth large population in the world. To see the employment of six provinces in Indonesia can be seen in Figure 3.

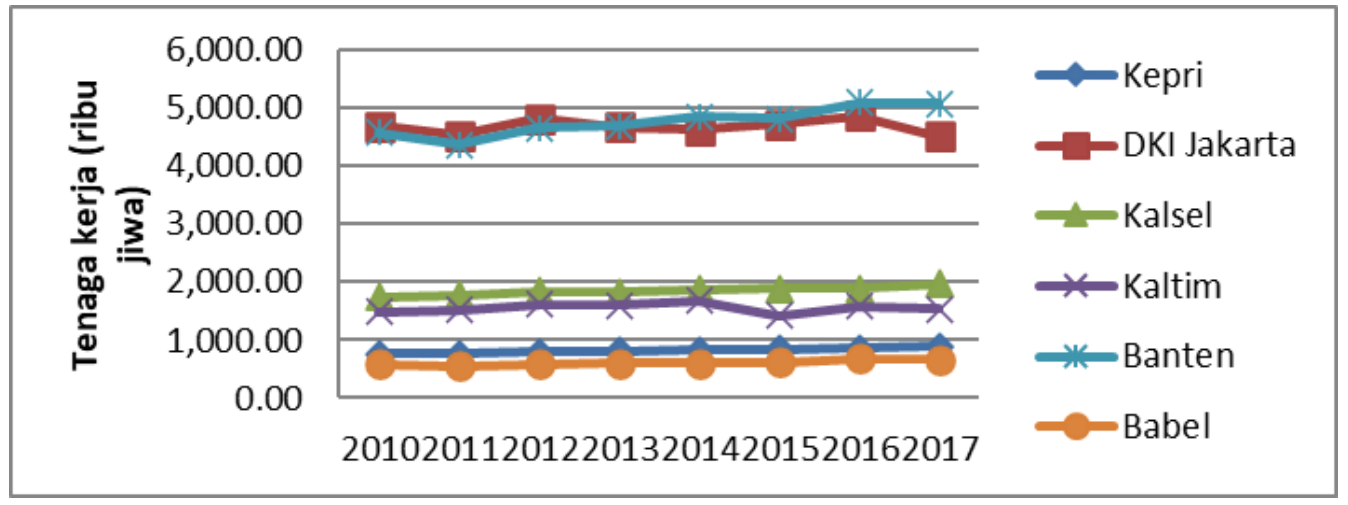

Figure 3. Population Working in Six Indonesian Provinces in 2010-2017 Source: BPS (2018) 
DKI Jakarta and Banten provinces both have more workforce than the four other provinces, but the number of workers from both fluctuate from year to year. The provinces that have a stable workforce and tend to increase are the Provinces of South Kalimantan, Riau Islands, and Bangka Belitung. A large number of workers in each of these provinces allows the region to increase production to encourage economic growth.

If we pay attention to the explanation above, the researcher tries to link the variables of economic growth with several variables such as trade openness, FDI, and labor. Several studies linking trade openness with economic growth have been carried out, but the results are still being debated. Some concluded that the relationship between trade openness and economic growth was positive, but other researchers concluded negatively. There are even studies that conclude that there is no relationship between trade openness and economic growth. Levine and Renelt (1992) concluded that the effect of trade openness on economic growth is unclear. They explained that trade openness encouraged FDI to increase due to tariff reduction measures. The positive effects of reducing tariffs will only be felt in the long run. Besides, the entry of foreign direct investment can cause domestic companies that cannot withstand increased competition to close their businesses.

Other researchers (Nowbutsing, 2014) analyzed the effect of trade openness on economic growth in the Indian Ocean Rim (IOR) member countries for 15 countries from 1997-2011. The independent variables used by Nowbutsing are trade openness, labor, inflation, gross fixed capital formation, and government spending. Nowbutsing uses three indicators of economic openness, namely the ratio of exports to GDP, the ratio of imports to GDP, and the ratio of exports and imports to GDP. His research results state that there is a positive relationship between openness and economic growth, while the workforce has a negative influence.

Ahmad et al. (2017) examined the effect of trade openness on economic growth in Pakistan in the 1975-2014 period. The independent variables used are Foreign Direct Investment, trade openness, and labor. The results of his research show that trade openness and FDI have a positive influence on economic growth, while labor has a negative effect. Whereas in Simorangkir's (2006) study, which conducted a study on trade openness to economic growth in Indonesia in the 1980-2005 period, the results showed that trade openness variables had a negative influence on economic growth.

Based on the description above, it appears that the effect of trade openness on economic growth is still being debated. Therefore, to determine the effect of trade openness on the economic growth of six provinces in Indonesia. Based on the phenomena that occur in the background, such as differences in theory with empirical data, especially provinces in Indonesia, as well as some references that have done previous research, the question is how the effect of trade openness, FDI, and labor on provincial economic growth in Indonesia. These questions will be answered after the research objectives can explain the results of the process of activities to be carried out in section four, namely, analyzing the effect of trade openness, FDI, and labor on economic growth.

\section{METHOD}

The type of data used in this study is panel data, with annual time series data for the period 20102017, and cross-section data covering six provinces in Indonesia, namely DKI Jakarta, Riau Islands, South Kalimantan, East Kalimantan, Banten, and Bangka Belitung. The variables used in this study are economic growth as the dependent variable, while the independent variables are trade openness, Foreign Direct Investment, and labor. The data is obtained mainly from BPS as secondary data, Bank Indonesia, OJK and other resources. The research method for taking the sample of the study is using a purposive sampling technique, which is chosen provinces that have moderate to high trade openness. Trade openness of more than 50 percent, and below 100 percent is included in moderate openness, while those above $100 \%$ are included in high openness (Nowbutsing, 2014). 
The variables used in this study are variables of economic growth, trade openness, foreign direct investment, and labor in each province. Economic growth is the real GDP with the base year 2010, the level of trade openness is the sum of exports and imports of goods and services to the GDP of each province. Furthermore, FDI is the volume of incoming investment to the country. Then, labor is the total of people who work in the selective sectors, see Table 2 below.

Table 2. Data, Symbols, Units, and Data Sources

\begin{tabular}{lclc}
\hline \multicolumn{1}{c}{ Variable } & Symbol & \multicolumn{1}{c}{ Unit } & Data source \\
\hline Economic growth & $\mathrm{Gr}$ & Percent & BPS \\
Trade openness & $\mathrm{TO}$ & Percent & BPS \\
Foreign Direct Investment & FDI & Million USD & BPS \\
Labor & $\mathrm{TK}$ & Thousand People & BPS \\
\hline
\end{tabular}

According to Widarjono (2017), there are several benefits obtained by using panel data, namely panel data can produce higher degrees of freedom and can overcome problems that arise when there are omissions or omitted variables. There are three approaches to the panel regression model, namely the common effect, fixed effect, and random effect approaches.

The model of the Common Effect approach is as follows: $\mathrm{Gr}^{\text {it }}=\beta^{0}+\beta^{1} \mathrm{TO}^{\text {it }}+\beta^{2} \mathrm{FDI}^{\text {it }}+\beta^{3} \mathrm{TK}^{\text {it }}+$ $\varepsilon^{\text {it }}$ (1) where: $\mathrm{Gr}^{\mathrm{it}}=$ Economic growth for province $\mathrm{i}$ in time $\mathrm{t}, \mathrm{TO}^{\mathrm{it}}=$ Trade Openness for province $\mathrm{i}$ in time $\mathrm{t}, \mathrm{FDI}^{\mathrm{it}}=$ Foreign Direct Investments for province $\mathrm{i}$ within $\mathrm{t}, \mathrm{TK}^{\mathrm{it}}=$ Labor for province $\mathrm{i}$ in time $\mathrm{t}, \mathrm{B}^{0}=$ intercept, $\mathrm{B}^{1,2,3}=$ Regression coefficient, $\varepsilon^{\text {it }}=$ Residual (error term)

Fixed Effect Model (Fixed Effect Model) approach is as follows: This estimation model is also called the Least Squares Dummy Variables (LSDV). This approach model is as follows: $\mathrm{Gr}^{\text {it }}=\beta^{0}+$ $\beta^{1} \mathrm{TO}^{\text {it }}+\beta^{2} \mathrm{FDI}^{\text {it }}+\beta^{3} \mathrm{TK} \mathrm{K}^{\text {it }}+\beta^{4} \mathrm{D}^{1 \mathrm{i}}+\beta^{5} \mathrm{D}^{2 \mathrm{i}}+\beta^{6} \mathrm{D}^{3 \mathrm{i}}+\beta^{7} \mathrm{D}^{4 \mathrm{i}}+\beta^{8} \mathrm{D}^{5 \mathrm{i}}+\varepsilon^{\text {it }}$ (2) where: $\mathrm{Gr}^{\mathrm{it}}=$ The dependent variable (economic growth) for unit i in time t, $\mathrm{TO}^{\mathrm{it}}, \mathrm{FDI}^{\mathrm{it}}, \mathrm{TK}^{\mathrm{it}}=$ The independent variables (trade openness, foreign direct investment, and labor) for unit $\mathrm{i}$ in time $\mathrm{t}, \mathrm{D}^{\mathrm{li}}=1$ for Riau Islands, 0 if not, $\mathrm{D}^{2 \mathrm{i}}=1$ for DKI Jakarta, 0 if not, $\mathrm{D}^{3 \mathrm{i}}=1$ for South Kalimantan, 0 if not, $\mathrm{D}^{4 \mathrm{i}}=1$ for East Kalimantan, 0 if not, $\mathrm{D}^{5 \mathrm{i}}=1$ for Banten, 0 if not, $\mathrm{B}^{0}=$ Interception, $\mathrm{B}^{1,2,3}=$ Coefficient slope, $\varepsilon^{\text {it }}=$ error term

According to Gujarati (2008), to avoid the dummy variable trap, a situation in which perfect collinearity occurs. We are given the freedom to choose which countries/regions are used as basic categories so in this case, the $\beta$ intercept $^{0}$ is the intercept value of a particular province. Thus $\beta^{4,5,6,7,8}$ indicates how much the difference between individual data intercepts with constants $\left(\beta^{0}\right)$.

Random Effect (REM) Approach is as follows: Random effect approach. This model estimates panel data, where interruption variables may be related between time and between individuals are as follows: $\mathrm{Gr}^{\text {it }}=\beta^{0}+\beta^{1} \mathrm{TO}^{\text {it }}+\beta^{2} \mathrm{FDI}^{\text {it }}+\beta^{3} \mathrm{TK}^{\text {it }}+v^{\text {it }}$ (3) where: $\mathrm{Gr}^{\text {it }}=$ The dependent variable (economic growth) for unit $\mathrm{i}$ in time $\mathrm{t}, \mathrm{TO}^{\mathrm{it}}, \mathrm{FDI}^{\mathrm{it}}, \mathrm{TK}^{\mathrm{it}}=$ The independent variable (trade openness, foreign direct investment, and labor) for unit i in time $\mathrm{t}, \beta^{0} \quad=$ Interception, $v^{\text {it }}=\varepsilon^{\text {it }}+\mu^{\mathrm{i}}$ $\beta^{0}$ no longer fixed or non-stochastic but random. $\mathrm{B}^{0}$ unknown parameter that shows the average population intercept and $\mu$ is a random interference variable that explains the differences in individual company behavior. The name of the random effect method comes from the understanding that the disturbance variable $v^{\text {it }}$ consists of two components, namely overall disturbance variables or a combination of time series and cross-sections and individual interruption variables. In this case, it is different between individuals and remains between time. Because the 
random effect model is also often called the Error Component Model (ECM). Because of the correlation between the disturbance variables, the right method to use is not OLS but GLS or Generalized Least Squares (Widarjono, 2017).

Panel data estimation consists of 3 types of approaches, namely Common Effect (PLS), Fixed Effect (FEM), and Random Effect (REM). To select the model that will be used, there are three tests, namely: (a) Chow Test (Likelihood Ratio), (b) Hausman Test, and (c) Lagrange Multiplier Test. The Chow test was carried out to determine whether the panel regression technique was performed with a common effect or with a fixed effect by looking at residual sum squares. Hausman Test is a statistical test conducted to choose the best modeling between Fixed Effect or Random Effect. The Langrage Multiplier test is done to choose the best modeling between Common Effects and Random Effects.

To use a valid model, a model test needs to be performed. The regression model test that will be used is to use classical assumptions, although not all regressions require the requirements of standard assumptions, such as logistic regression or ordinal regression. The classic assumption test that is often used is multicollinearity detection, heteroscedasticity test, normality test, autocorrelation test, and linearity test. There are no definitive provisions about which order of testing must be met first (Widarjono, 2017).

The normality test in this study carried out by the Jarque-Bera test. The hypothesis used: $\mathrm{H}^{0}$ : residuals are normally distributed, $\mathrm{H}^{\mathrm{a}}$ : residuals are not normally distributed. With the following testing criteria: Jarque Bera stat $>\mathrm{x}^{2}$ table, $\mathrm{p}$-value $<5 \%, \mathrm{H}^{0}$ received, Jarque Bera stat $\left\langle\mathrm{x}^{2}\right.$ table, $\mathrm{p}$ value $>5 \%, \mathrm{H}^{0}$ received, $\mathrm{H}^{0}$ rejected. Multicollinearity Detection Test is to detect whether there is a linear relationship between the independent variables in multiple regression in an equation. The criteria used, if the correlation value $<0.85$, there will be no multicollinearity, whereas if the correlation value $>0.85$, it can be said that there is no multicollinearity. Heteroskedasticity Test is to find out whether the variance of the residual regression model used in the study is not homoscedasticity or, in other words, it is not constant or there is an inequality of variance from one residual to another observation. The regression model that meets the requirements is where there is a similarity in variance from one observation residual to another observation that is fixed or called homoscedastic. The detection method uses the White Heteroskedasticity method, namely by comparing the value of Obs $* \mathrm{R}$-square $\left(\chi^{2}\right.$ count), if $\chi^{2}$ count $>$ Chi-Square $\left(\chi^{2}\right.$ table $)$, means there is a heteroscedasticity problem in the model and vice versa. Autocorrelation Test, i.e. is detecting a correlation between members of one observation with other observations that are different in time, the method used to test autocorrelation is the Breusch-Godfrey Serial Correlation LM Test method.

\section{RESULTS AND DISCUSSION}

Used to test a better model between FEM and CEM, which is to see the probability value of the Chow test with the following hypothesis: H0: Differential constant is zero (CEM), probability > real level (alpha), Ha : Differential constant is not zero (FEM), probability < real level (alpha)

Table 3. Chow Test Results

\begin{tabular}{lrrr}
\hline \multicolumn{1}{c}{ Effect Test } & \multicolumn{1}{c}{ Statistics } & \multicolumn{1}{c}{ Df } & \multicolumn{1}{c}{ Prob. } \\
\hline Cross-section F & 7,814590 & $(5,39)$ & 0,0000 \\
Chi-square cross-section & 33,315935 & 5 & 0,0000 \\
\hline
\end{tabular}

Source: Data processing results, Appendix 2

Based on Table 3. shows both the F value and Chi-Square has a p-value of 0.0000 or smaller than the real level of 5 percent $(0.05)$, so reject $\mathrm{H} 0$ and accept Ha. Then the fixed-effect method is better used in research. 
Hausman test is done to choose the best model between Fixed Effect or Random Effect. The hypothesis of testing is: $\mathrm{H}^{0}=$ choose the Random Effect model if the Hausman value <chi square table value, $\mathrm{H}^{\mathrm{a}}=$ choose Fixed Effect model if Hausman value $>$ chi-square table value.

Table 4. Hausman Test Results

\begin{tabular}{cccc}
\hline Summary Test & Chi-Sq. Statistics & Chi-Sq. df & Prob \\
\hline Random cross section & 9,864706 & 3 & 0,0198 \\
\hline
\end{tabular}

Source: Data processing results, Appendix 3

Based on Table 4, the Hausman statistical value of 9.864706> Chi-Square table value (7.81) with a probability value of 0.0198 is smaller than the 5 percent real level, $\mathrm{H} 0$ is rejected, so it can be concluded that the fixed effect method is better than the Random Effect. From the two tests that have been done, it can be concluded in this study that the Fixed Effect Model is considered better for use and was chosen as an analysis tool.

The normality test is used to determine whether in the regression model, the dependent variable and the independent variable have residual values that are normally distributed.

Table 5. Normality Test Results

\begin{tabular}{cccc}
\hline Skewness & Kurtosis & Jarque-Bera & Prob. \\
\hline 0.034123 & 3,026879 & 0,010760 & 0,994635 \\
\hline
\end{tabular}

Source: Data processing results, Appendix 4

Table 5 shows the value of Jarque Bera $=0.0100760<\chi^{2}$ table $(6)$ with a probability of $0.994635>$ 0.05 , the null hypothesis which states that the residues are typically distributed is accepted.

Table 6. Multicollinearity Detection Results

\begin{tabular}{ccrr}
\hline & INTO & LnFDI & \multicolumn{1}{c}{ LABOR } \\
\hline INTO & 1,000000 & 0,190179 & 0,003737 \\
LnFDI & 0,190179 & 1,000000 & 0,837748 \\
LABOR & 0,003737 & 0,837748 & 1,000000 \\
\hline
\end{tabular}

Source: Data processing results, Appendix 5

According to Widarjono (2017), if the correlation coefficient is quite high, i.e. above 0.85 , it is assumed that there is multicollinearity in the model. Seen from Table 7, it appears that the correlation coefficient between independent variables is smaller than $0.85(<0.85)$, so there is no multicollinearity problem.

Heteroskedasticity test is used to find out whether the disturbance variable has an average of zero, has a constant variant, or in other words, whether there is homoskedasticity or heteroskedasticity. The method used is the white method, with the hypothesis proposed as follows.

Table 7. Heteroskedasticity Test Results

\begin{tabular}{ccl}
\hline Chi-square count & Chi-square table & \multicolumn{1}{c}{ Conclusion } \\
\hline 12 & 7,81 & $\begin{array}{l}\text { There is no heteroskedasticity } \\
\text { problem }\end{array}$ \\
\hline
\end{tabular}

Source: Data processing results, Appendix 6

Table 7 shows that $\chi 2$ count of 12 is greater than $\chi 2$ table at a significance level of $5 \%$ and df as many as independent variables. So that heteroskedasticity occurs. To overcome this cross-section weight method, thus the regression results have been avoided from the problem of heteroskedasticity. 
This study is to detect autocorrelation problems in panel data using the Breush-Godfrey method which is calculated manually by regressing the residuals obtained from the research regression equation to the independent variables and lags of the research residuals to obtain R 2 values that are later multiplied by the number of observations in the study.

Table 8. Autocorrelation Test Results

\begin{tabular}{ccc}
\hline Chi-square count & Chi-square table & Conclusion \\
\hline 6,12 & 5,99 & There is an Autocorrelation problem \\
\hline
\end{tabular}

Source: Data processing results, Appendix 7

By using the Breush-Godfrey method, obtained $\chi 2$ count of 6.12 is more significant than $\chi 2$ tables at a significance level of 5 percent and $\mathrm{df}=2$, namely the number of lengths of residual inaction. Nevertheless, there is an autocorrelation problem. The solution is to use the white method, namely by changing the coef. covariance method in the options panel to become a white cross-section so that the regression equation becomes a regression equation that is free from autocorrelation problems.

Based on the results of the chow test and the Hausman Fixed Effect Model test was rated the best for analyzing data in this study. The results of the regression calculations are in Table 10.

Table 9. Results of the Fixed Effect Model Regression Calculation

\begin{tabular}{crrrr}
\hline Variable & Coefficient & \multicolumn{1}{c}{ Std. Error } & \multicolumn{1}{c}{ t-statistic } & \multicolumn{1}{c}{ Prob. } \\
\hline C & 23,12590 & 9,955686 & 2,322884 & 0,0255 \\
TO & 2,448736 & 0,992692 & 2,466762 & 0,0181 \\
FDI & $-0,875586$ & 0,152225 & $-5,751908$ & 0,0000 \\
TK & $-3,098257$ & 1,451354 & $-2,134735$ & 0,0391 \\
\hline
\end{tabular}

Source: Data processing results, Appendix 1

Based on the results of the Fixed Effect Model regression calculations, the resulting econometrics model is: Grit $=(0.0255)(0.0181)(00.0000)(0.0391), \mathrm{R} 2=0.626185, \mathrm{~F}$ arithmetic $=8,166221$.

Based on the regression results in Table 9, all independent variables, namely Trade Openness, FDI, and Labor, have a probability value of less than 0.05 . The null hypothesis is rejected or accepts an alternative hypothesis. In other words, the trade openness variable (TO) significantly influences the economic growth of the provinces in Indonesia, and both have a positive relationship. While the variable foreign direct investment (FDI) also influences and significantly affects the economic growth of provinces in Indonesia, but has a negative relationship. Likewise, the labor variable also has a negative and significant effect on the economic growth of the provinces in Indonesia. For F-statistic testing, it is also significant, which means that together with the independent variables in the model influence the economic growth of provinces in Indonesia. Based on the results of testing, the best model used to analyze data in this study is the Fixed Effect Model. Following are the regression coefficients obtained from the Fixed Effect Model (FEM) approach.

Trade openness has a positive and significant impact on economic growth in Indonesia's provinces. The regression coefficient is 2.45 , meaning that every $1 \%$ increase in the value of trade openness will have an increasing effect on the economic growth of $t$ by $2.45 \%$ ceteris paribus. These results are consistent with the theory of international trade both from Adam Smith and David Ricardo (Salvatore, 2014), who recommend that each country conducts international trade to encourage economic growth. By conducting international trade, a country can get many benefits, including obtaining goods or services that are inefficient or even cannot be produced in their own country, 
benefit from specialization, have a broader market, transfer technology from more developed countries, and so on.

Likewise, the results of research conducted by Clemes and Williamson (2002), that economic openness affects growth, which means that the relative value of economic openness, which is a condition of international trade will have an impact on economic growth. The results of this study are also supported by research by Chen and Gupta (2006), Nowbutsing (2014) and Febriyastuti (2017) which state that trade openness has a positive and significant effect on economic growth, so this is consistent with the hypothesis at the beginning of the study.

The size of the value of trade openness is very dependent on the size of the export and import values of provinces in Indonesia. Although trade openness has a positive and significant relationship to economic growth, the magnitude of influence on economic growth is highly dependent on the value of trade openness, namely the value of exports and imports, considering trade openness is the ratio of the sum of export and import values to the GRDP. Both the value of exports and the value of imports for a province or country are significant in increasing economic activity.

If exports can increase due to domestic production which is not consumed in excess, then imports can also increase exports, if what is imported is technology, capital goods, and raw materials which are lacking or even not owned by a country. Our country Indonesia is also still very dependent on the import of technology, capital goods, and certain raw materials. Efforts to substitute imports for various production inputs have been carried out for a long time, but the fact is that they have not been able to make a significant contribution to encourage the growth of Indonesia's exports. Some of Indonesia's production is still very dependent on imported resources. So that the disruption of the rupiah against the US dollar can disrupt the development of products in Indonesia. However, the fact is that until now, it has not been able to make a significant contribution to driving Indonesia's export growth.

Some of Indonesia's production is still very dependent on imported resources. So that the disruption of the rupiah against the US dollar can disrupt the development of products in Indonesia. However, the fact is that until now, it has not been able to make a significant contribution to driving Indonesia's export growth. Some of Indonesia's production is still very dependent on imported resources, so that the disruption of the rupiah against the US dollar can disrupt the development of products in Indonesia.

In addition to the importance of the value of trade openness, another problem that often occurs is the problem of the trade balance deficit. The magnitude of the value of imports can also pose a risk to the stability of the Indonesian economy. However, if seen from the data in this study during the 2010-2017 period, four provinces had export values more significant than the import value, namely Bangka Belitung Province, East Kalimantan, South Kalimantan, and Riau Islands. This is undoubtedly good for Indonesia's trade balance. However, there are also two provinces, namely DKI Jakarta and Banten, which have import values more significant than the export value or deficit. Therefore, efforts to maintain and increase the degree of trade openness need to be carried out by the government, bearing in mind that trade openness has a positive impact on economic growth. However, in this case, regional or provincial governments should strengthen domestic markets, namely by implementing policies to encourage exports in leading sectors in each province. 
In other words, encouraging commodities that have huge comparative advantages, then importing commodities to support domestic commodity production which cannot be carried out by Indonesia yet, namely by carrying out and controlling imports of consumptive and luxury commodities. This was done aiming to reduce the trade balance deficit caused by high imports. Regional or provincial governments should strengthen domestic markets, namely by implementing policies to encourage exports in leading sectors in each province. In other words, encouraging commodities that have huge comparative advantages, then importing commodities to support domestic commodity production which cannot be carried out by Indonesia yet, namely by carrying out and controlling imports of consumptive and luxury commodities. This was done aiming to reduce the trade balance deficit caused by high imports. Regional or provincial governments should strengthen domestic markets, namely by implementing policies to encourage exports in leading sectors in each province. In other words, encouraging commodities that have huge comparative advantages, then importing commodities to support domestic commodity production which cannot be carried out by Indonesia yet, namely by carrying out and controlling imports of consumptive and luxury commodities.

This was done aiming to reduce the trade balance deficit caused by high imports. It was then importing supporting commodities for domestic commodity production, which cannot be carried out by Indonesia yet, namely by carrying out and controlling imports of consumptive and luxury commodities. This was done aiming to reduce the trade balance deficit caused by high imports. It was then importing supporting commodities for domestic commodity production, which cannot be carried out by Indonesia yet, namely by carrying out and controlling imports of consumptive and luxury commodities. This was done aiming to reduce the trade balance deficit caused by high imports.

The FDI variable has a negative and significant effect on economic growth with a coefficient of 0.88 , which means that any increase in FDI of $1 \%$ will cause economic growth to decrease by $0.87 \%$ ceteris paribus. The results of this calculation are not in line with the hypothesis. However, the hypothesis is built from the theoretical and empirical concepts that FDI does not always have a positive influence on economic growth because FDI can encourage the emergence of industrial dominance, increase technological dependence, influence cultural change.

The dominance of FDI can cause disruption to economic planning due to intervention from the investor country. By sector, it is possible that this international capital flow will be opposed by certain groups of production factors owners because of the redistribution of income from owners of other factors of production to the owners of capital. Also, the inclusion of FDI can have a negative influence on a country's economic growth because it can increase the technological dependence of recipient countries and can threaten the presence of domestic companies that are unable to compete so that it will shut down.

Besides, the negative effect of FDI on the economic growth of provinces in Indonesia is also caused by the condition of FDI development in the Indonesian province, which is still volatile. Indonesia is not yet a priority as a place to invest capital for foreign investors. A study conducted by UNCTAD in 2006 placed Indonesia as a less desirable region, and the performance and potential inflows of foreign investors were in a low category (Kholis, 2012). The contributing factors are the number of barriers to entry for foreign investors, inefficient bureaucracy, unfavorable infrastructure, and land acquisition issues are also reasons why Indonesia is still less attractive to foreign investors.

So that FDI in Indonesia cannot be used optimally to increase economic growth. It is because the FDI that comes to Indonesia is mostly capital accumulation. The lack of foreign investor interest in 
entering Indonesia, including in the provinces in Indonesia, needs to be observed by the government as a warning to pay more attention to the policies of this sector in order to encourage better economic growth. Increasing competition among countries in the world to attract foreign investment or FDI encourages every country, including Indonesia, to further improve the investment climate that is more in line with investor demands.

It must be realized that in fact, foreign investors have understood the conditions and characteristics of a country, so that any policies that are rolled out by a country will be monitored by investors. The results of this study are also supported by research Malefane and Odhiambo (2018) which found a negative relationship between FDI and economic growth both in the short and long term as well as in research Molood Raki and Sareh Amirmojahedi (2012) which found a negative and significant relationship between Foreign Direct Investment to economic growth.

Regression estimation results show that the labor variable has a negative and significant effect on economic growth at a 95\% confidence level, which means an increase in labor means that economic growth will decline. The labor regression coefficient value of -3.098 , meaning that each increase of labor by 1 percent will cause economic growth to decrease by $-3.09 \%$ ceteris paribus.

The results of this study, which produced a negative coefficient, are likely caused by the population growth that is quite high in Indonesia, causing various problems and obstacles in economic development, especially employment issues. Todaro (2011)stated that rapid population growth led to the problem of underdevelopment and made development prospects even further behind. In Indonesia, the problem of population development is related to three things, namely the relatively high population growth rate. Hence, it needs to be continued to decrease by intensifying programs to limit the number of children born, the spread of population between regions that are less balanced, and the quality of life of the population that is still low, so the condition needs to be improved.

In theory, actually, according to Todaro (2011) states, that population growth and labor growth is one of the decisive factors that can spur economic growth. A large number of workers means that it will increase the level of production, while higher population growth means that the size of the domestic market is more significant. Furthermore, it is said that the positive or negative effect of labor growth depends on the ability of a country's or regional economic system to absorb and productively utilize the increase in labor. In other words, it depends on the amount of employment elasticity that can be created by economic growth. This ability is also influenced by the level and type of capital accumulation and the availability of supporting factor inputs such as managerial and administrative capabilities. In other words, the abundant quantity of labor must be followed by the quality it has.

When viewed in these conditions in Indonesia, which is one of the countries with a large number of workers, but the level of education possessed by workers is still relatively low, in addition it also lacks skills. Educated labor of university graduates in Indonesia is less than $10 \%$, the still low number of educated workforces causes it cannot produce high productivity and is efficient and cannot master technology, so it will affect the output produced. This is according to Simanjuntak (1985) in Fitriani (2017), because educators provide knowledge not only that is directly with the implementation of the task, but also the foundation to develop themselves and the ability to use all the facilities that are around for the smooth implementation of the task.

The faster technological progress will be more effective if used by skilled and trained workforce. Thus, the lower the level of education the lower the work productivity will be, so that the end result is less than optimal economic growth. Results of similar studies have also been carried out before Nowbutsing (2014), which states that, the negative influence can be caused by several things, namely: (1) There is a tendency of highly educated workers who do not work in their area, but work outside their original area. In other words, people studying abroad, after finishing not 
returning to their home country, but working abroad, for example, in developed countries, (2) The available work does not match the education and skills of the workers thus affecting their productivity to be suboptimal, as a result, it can lead to suboptimal economic growth, even tending to decline due to high but less productive performances.

Table 10. Individual effects of Six Provinces

\begin{tabular}{lrr}
\hline \multicolumn{1}{c}{ Fixed Effects (Cross) } & Coefficient & Individual Effect \\
\hline Bangka Belitung & $-3,958$ & 19,167 \\
Banten & 5,474 & 28,599 \\
DKI Jakarta & 4,846 & 27,971 \\
South Borneo & $-0,925$ & 22,201 \\
East Kalimantan & $-1,480$ & 21,645 \\
Riau islands & $-3,955$ & 19,171 \\
\hline
\end{tabular}

Source: Data processing results, Appendix-1

The value of personal effect or cross-section effect is used to show how big the difference or ranking of economic growth in each province is in Indonesia, as a result of the influence of variable variables on economic growth in each province. So, it will appear which provinces are the highest and the lowest in Indonesia. The difference is following the model on FEM, which has a dummy as much as the number of regions or as cross data in this study. To find out the differences in economic growth in the six selected provinces in Indonesia, see Table 8. Based on the results in Table 8, it appears that the Banten provinces and DKI Jakarta have significant economic growth compared to other provinces, namely South Kalimantan, East Kalimantan, Riau Islands, and Bangka Belitung provinces respectively. Banten Province and DKI Jakarta have high constants; these conditions indicate that economic activity in the two regions is very high so that more factors of production, both labor, capital, and raw materials, as well as economic actors absorbed in the two regions. Likewise, the level of progress and density is also very high whereas the two provinces in Kalimantan, namely South Kalimantan and East Kalimantan have lower constants compared to Banten and DKI Jakarta.

\section{CONCLUSION}

Based on the results of data analysis and discussion described, the following conclusions are obtained: The level of trade openness has a profound effect on improving economic growth. We can see this condition from countries that already have a high degree of trade openness both in developed and developing countries. The amount of trade openness contribution to economic growth will also have a fully positive impact on domestic economic activities. However, if the degree of openness of foreign trade is still relatively low, it can have the opposite effect, which does not contribute to the domestic economy. This research has proven that, although the openness of foreign trade in Indonesia's provincial regions has a positive effect because the degree of openness is still relatively low, this condition causes its contribution to the domestic economy to remain low. It often causes problems in the domestic economy, for example, the declining growth of newly developing products (infant industry) in various sectors. So that it will reduce the absorption of workers in the affected sectors. Likewise, the attractiveness of foreign investors to invest their capital in the provinces of Indonesia is still low due to various obstacles, both bureaucratic and infrastructure constraints. Therefore, it is necessary to pay attention to the central and regional governments so that they can jointly open facilities and attractions by suppressing existing barriers. So that it can create an attraction for foreign and domestic investors to invest in provinces in Indonesia, so that economic growth sourced from foreign trade activities can become more critical for the domestic economy. 


\section{REFERENCE}

Arora, V B. \& Vamvakidis. A (2004). How Much Do Trading Partners Matter for Economic Growth? IMF Working Paper.

Chang, C \& Mendy, M. (2012). Economic Growth and Openness in Africa: What is Empirical Relationship? Applied Economics Letters. 19: 1903-1907

Chang, R., Kaltani, L. \& Loayza, N. (2006). Openness Can be Good for Growth: The Role of Policy Complementarities. Journal of Development Economics. 90: 33-49

Chang, R., Kaltani, L. and Loayza, N. (2006). Openness can be good for Growth: The Role of Policy Complementarities.

Chen, P. \& Gupta, R. (2006). An Investigation of Openness and Economic Growth Using Panel Estimation. Department of Economics Working Paper Series.

Chen, P. and Gupta, R. (2006). An Investigation of Openness and Economic Growth Using Panel Estimation.

Clemens \& Williamson. (2002). Why Did the Tariff- Growth Correlation Reverse After 1950? Economic Paper.

Fitria, A. Y. (2011). Analisis Pengaruh Foreign Direct Investmen terhadap Pertumbuhan Ekonomi Negara ASEAN Tahun 1980-2009 (Skripsi). Institut Pertanian Bogor.

Jhingan, M. L. (2008). Ekonomi Pembangunan dan Perencanaan Edisi Keenambelas.Jakarta: PT Raja Grafindo Persada.

Khan, M. T. I . (2014). Trade Openness and Economic Growth in the Asian Region. Department of Management Sciences, Comsats Institute of Information Technology, Abbottabad, Pakistan

Kholis, M. (2012). Dampak Foreign Direct Invetsment terhadap Pertumbuhan Ekonomi Indonesia. Vol.8 No.2

Malefane, R. M. (2018). Impact of Trade Openness on Economic Growth : Empiris Evidence from South Africa. Unisa Economic Research Working Paper Series.

Marbun, E. (2018). Pengaruh Trade Openness dan Foreign Direct Investment terhadap Gross Domestik Produk (GDP) di Indonesia (Skrispi). Universitas Lampung.

Nowbutsing, B. M. (2014). The Impact of Openness on Economic Growth: Case of Indian Ocean Rim Countries. Journal of Economics and Development Studies. Vol. 2 No. 2, pp. 407427

Pohan, F. S.. (2018). Trade Openness Effect on Income Inequality: Empirical Evidence from Indonesia Lestari Agusalim.

Prastity, N. \& Cahyadin, M. (2015). Pengaruh Foreign Direct Investment dan Trade Openness terhadap Pertumbuhan Ekonomi di Negara Anggota Organisasi Islam (OKI) 2000-2003. Vol. 20 No. 3

Salvatore, D. (1997). Ekonomi Internasional Edisi Lima. Jakarta: Erlangga

Simorangkir, I. (2006). The Openness and its Impact to Indonesian Economy: A Structural Var Approach.

Simorangkir, I. (2008). The Openness and its Impact to Indonesian Economy: Structural Var Approach. Buletin Ekonomi Moneter dan Perbankan.

Sukirno, S. (2000). Makroekonomi Modern. Jakarta: PT Raja Grafindo Persada.

Susilo, J. H., Tsani, L. I., Herianto., M. K. (2020). Econometrics Model of Economic Growth in East Java Province with Dynamic Panel Data through Arellano-Bond Generalized Method of Moment (GMM). Economics and Development Studies University of Diponegoro.

Tambunan, T. (2000). Perdagangan Internasional dan Neraca Pembayaran; Teori dan Temuan Empiris. Jakarta: LP3ES.

Todaro, M. P. \& Smith, S. C. (2003). Pembangunan Ekonomi di Dunia Ketiga. Jakarta: Erlangga

Widyawati, R. F. (2017). Impact of Openness of International Trade, Human Capital and Capital Flow on Economic Growth of ASEAN-5 Countries 1993-2013. 
Yanikkaya, H. (2002). Trade Openness and Economic Growth: a Cross-Country Empirical Investigation. College of Business and Administrative Sciences, Celal Bayar University, Uncubozkoy Kampusu, Manisa 45030, Turkey 